\title{
BUILDING COALITIONS: Tapping Private Sector Resources
}

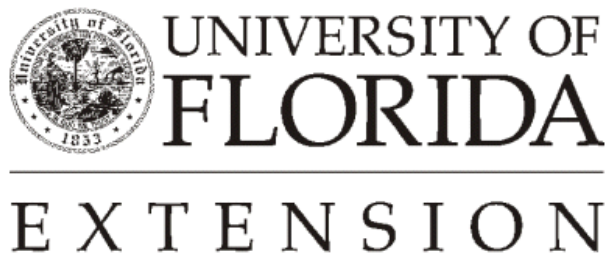

Institute of $\mathbf{F}_{\text {ood and }} \mathbf{A}_{\text {gricultural }} \mathbf{S}_{\text {ciences }}$ 
Today's private sector is more involved with nonprofit groups than ever before. They realize that there is a shortage of resources available from government sources at every level and are interested in helping communities to be healthy vibrant places in which to raise families.

A big key to using the private sector effectively is to make them an integral part of your program. F or example, does your board of directors have members of industry, private citizens and representatives from small business? Are your programs using volunteers from the private sector? Does your group offer services that would be valuable to employees at the local factory?

There are many resources available in the private sector. To get them excited about what you do, involve individuals from their company in your programs. Start by looking at yourself.

\section{Self Examination}

Examine your organization. Figure out who you are, where you are, where you want to be and what you need to get there.

This evaluation should be done regularly, at least once a year. It should include receiving direction from both external and internal sources and involve feedback from everyone connected with the organization. There will be difficult questions and answers. It is important that you are honest.

\section{Identify Total Resources}

Successful groups should be able to manage a variety of resources. Start within the organization, determine your needs, then identify available resources. Begin within your organization and work outward into the community. There are renewable resources such as staff, directors, volunteers, members and consumers of your services, others who share your cause and everyone who benefits from your service, directly or indirectly.

You will discover that resources are available from a variety of sources. These may offer multiple resources that would be valuable. You will discover that these sources will be interconnected. Four major resource groups-- money, people, good and services-work together and independently to meet community needs.

\section{Money}

The importance of money to service organizations is obvious. Everyone has money. Eighty-six percent of Americans give to one or more charitable organizations. They represent all ages, incomes, occupations and education levels.

Ninety percent of donations come from individuals. The remaining percentage comes from foundations and corporations. The key is to look for total resources. While corporations and foundations may be the 
source of some big single donations, individual giving will add staying power. Corporations are more likely to give money if they know the community at large is also supportive of your efforts.

Donations aren't the only source of money. There are others--investment income; membership dues; earned income from businesses, goods and services; government grants and contracts; and program-related investments.

\section{People}

In most service-oriented nonprofit groups, people are the key to all resources--money, more people, goods and services. People resources are persons giving their time free of charge, for a small fee, or for payment by a third party on a nonprofit's behalf. People resources are not only volunteers. People do volunteer their services, but employers may give release time to employees to work on worthwhile community efforts.

Because people are everywhere, know everyone and do everything, their resource potential is unlimited. The challenge is to discover how to use the most people, in the best combination, to the organization's greatest advantage.

\section{Goods}

Any personal property, excluding money and securities, is a good. Goods are a vital non-cash resource for any organization. It is often called a money substitute. Successful groups use goods as complements to their other resources for a total resource package.

Some of the best examples of goods are office furniture, equipment and supplies. Goods, like money, are everywhere--in homes, businesses, governments, civic groups, etc. Some possible arrangements for using goods are used or surplus goods, new products and merchandise, loaned goods and goods purchased cooperatively with another group.

\section{Services}

Services are grouped with goods as in-kind gifts. Many overlook services because with few exceptions, services are not tax deductible as a charitable contribution. Some companies deduct the time used in performing a charitable service as a normal business expense. Others consider community service a business function and keep no record of its performance. Yet, services are a major source of support to successful nonprofit groups.

Corporations are the best known contributors, but the giving of services is undoubtedly a community affair; small businesses, vendors, colleges, other nonprofits, individual professionals and tradespeople. Everyone providing services for a fee are probably also providing it free, or at a discount, for some worthy cause. 


\section{Summary}

Nonprofit groups today are facing more complex problems than ever before, and it often seems that resources are decreasing. The private sector offers many resources that are limited only by the imagination of the stakeholders involved.

The complex problems of today require the input of a more diverse group of problem solvers. To get this involvement in your organization, seek help from the private sector and make its members a part of your organization. It could prove rewarding to everyone involved. 


\section{References}

Adapted from Discover Total Resources, The Mellon Bank Corporation, Pittsburgh, Pennsylvania, 1985.

\section{(C) 1992 The Ohio State University}

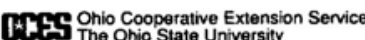

This series on Coalition Building was developed by The Ohio Center For Action on Coalition Development for Family and High Risk Youth, Richard Clark, Ph.D., Director. It has been adapted for County Extension Faculty in Florida to facilitate work with local and regional organizations and groups such as non-profits, cooperatives, county extension associations, and others that might benefit from a plan for working together to achieve support for mutual goals.

This document is FY505, Part 13 of the 16 part series adapted for use in Florida by Elizabeth B. Bolton, Professor, Community Development and Lisa Guion, Assistant Professor, Program Planning and Evaluation; Department of Family, Youth and Community Sciences, Florida Cooperative Extension Service, Institute of Food and Agricultural Sciences, University of Florida, Gainesville, 32611-0310.

Reprinted with permission March, 1997. Revised April, 2002.

The Institute of Food and Agricultural Sciences is an equal opportunity/affirmative action employer authorized to provide research, educational information and other services only to individuals and institutions that function without regard to race, color, sex, age, handicap, or national origin. For information on obtaining other extension publications, contact your county Cooperative Extension Service office.

Florida Cooperative Extension Service/Institute of Food and Agricultural Sciences/University of Florida/Christine Taylor Waddill, Dean 